\title{
The family Isoëtaceae in Guerrero, Mexico: A new record
}

\author{
ERnesto VeláZquez-Montes \\ Departamento de Biología Comparada, Laboratorio de Plantas Vasculares, Facultad de Ciencias, \\ Universidad Nacional Autónoma de México, México, D.F., México \\ vme@unam.mx
}

\begin{abstract}
Despite the intensive taxonomic studies on pteridophytes carried out in Mexico, particularly in the state of Guerrero, Isoëtaceae has not yet been reported in this state. Here the first report of Isoëtes pallida in the southeastern coastal plain near Acapulco is given and discussed. The finding of I. pallida in the state of Guerrero is the third record of this taxon in the country. Currently, the color and ornamentation of the sporangial wall are used to separate some species of Isoëtes, but the taxonomic value of these characteristics seems to be questionable.
\end{abstract}

Key words: Guerrero, Isoëtes pallida, new record, Pteridophytes, taxonomy.

Resumen: A pesar de los intensos estudios taxonómicos sobre pteridofitas realizados en México, particularmente en el estado de Guerrero, Isoëtaceae no había sido reportada. Se registra el hallazgo de Isoëtes pallida, localizada en la planicie costera, cerca de Acapulco y es el tercer registro de este taxón en el país. El color y la ornamentación de la pared del esporangio son utilizados generalmente para separar algunas especies de Isoëtes; sin embargo, el valor taxonómico de estos caracteres parece estar en duda.

Palabras clave: Guerrero, Isoëtes pallida, nuevo reporte, Pteridofitas, taxonomía.

I soëtaceae is one of three families with living representatives, with Lycopodiaceae and Selaginellaceae, which belong to ancient group of plants known as Lycophytes. Since its long evolutionary history which dates to the Devonian times, ca. 400 million years ago (Judd et al., 2008), this family has a great fossil record. For example, those species with an herbaceous and homosporous habit, like Asteroxylon, Barawanathia, Drepanophycus, as well as those that became arborescents and heterosporous during Carboniferous, like Lepidodendron and Pleuromeia among others; however, Isoëtaceae, with an atypical secondary growth anatomy, has an herbaceous habit and represents the end of this latter evolutionary line (Pigg, 1992). The earliest forms similar to the modern Isoëtes belong to Triassic (Taylor et al., 2009).

Isoëtaceae is monotypic, and contains the extant genus Isoëtes (Pfeiffer, 1922; Christenhusz et al., 2011). Stylites, from Peru and Bolivia, has been recognized as distinct genus in this family (Amstutz, 1957), but is regarded by most authorities as another morphologic form of Isoëtes (Taylor et al., 2009). The family is a monophyletic assemblage based on the following synapomorphies: embedded, indehiscent, and trabeculate sporangia, labia, leaves with four air chambers, and reduced axial growth (Taylor and Hickey, 1992).
This family contains from 130 (Jermy, 1990) to more than 200 species in the world (Mickel and Smith, 2004). It is of a worldwide distribution, occurring in Europe, Africa, Asia (China, Japan, India), Indonesia (New Guinea, Sumatra), Australia, New Zealand, and Tasmania; in America from Alaska and southern Greenland to Magallanes in Chile (Tryon and Tryon, 1982).

Isoëtes howellii Engelm., I. mexicana Underw., I. montezumae A.A.Eaton, I. orcuttii A.A.Eaton, I. pallida Hickey, and I. pringlei Underw. are distributed in Mexico (Mickel and Smith, 2004). This genus has a great percentage of endemism due to ecological isolation (Jermy, 1990), and in Mexico, I. mexicana and I. pringlei are the only endemic species, but $I$. montezumae from Mexico and Guatemala, $I$. orcuttii, from the state of California, United States of America, and Baja California Norte, Mexico, and I. pallida, from $\mathrm{S}$ of Mexico and Belize, may be considered endemic under Megamexico 3 concept of Rzedowski (1991).

Isoëtaceae is well represented in America with ca. 60 species (Tryon and Tryon, 1982). In north America, including northern Mexico together with the United States, Canada, Greenland, and some minor islands, 24 species have been recorded, but only two of them, I. orcuttii and I. howellii, 
are present in Mexico (FNAEC, 1993). In Guatemala there are three species: I. cubana Engelm., I. panamensis Maxon $\&$ Morton, and I. montezumae, and the latter, as had been said, is present in Mexico too (Stolze and Hickey, 1983). Nelson et al. (1996) did not record Isoëtaceae in Honduras, and León (2006) had recorded ten species for Peru, which is considered as a center of diversification. Seven species have been reported from the Guanabara region and adjacent states in Brazil (Tryon and Tryon, 1982).

Isoëtaceae is distinguished because contains perennial plants, stems corm-like with the roots arising along central groove; leaves microphylls, linear-lanceolate, simple, spirally or less common distichous arranged, erect or spreading, straight to recurved, $1-100 \mathrm{~cm}$ long, ligulate above sporangium, with four air chambers around the midvein as seen in transverse section which are internally septate; sporangia heterosporous, solitary, adaxial, embedded in basal cavity of leaf, covered or not by a velum, indehiscent, internally trabeculate, each one with several to hundreds of megaspores or thousands of microspores; megaspores white, gray or black, triletes, with an equatorial ridge, their surface is smooth, spiny, tuberculate or pustulate, 290-700 $\mu \mathrm{m}$ in equatorial diameter; microspores grayish or brownish in mass, monoletes, their surface smooth or with spines, tubercles or ridges, 20-50 $\mu \mathrm{m}$ long (FNAEC, 1993; Mickel and Smith, 2004).

Most species are very difficult to find out and recognize in the field because they are extremely rare and closely resemble, in gross morphology and growth habit, to some grasses and other semi-aquatic plants like Cyperaceae and Juncaceae. Currently, Isoëtes is submerged in the water or their lower part in the mud with only the top of the leaves emerging, thus requiring a very careful search, and a skilled eye. As a result, very few specimens have been collected, at least in Mexico.

The research project Flora of Guerrero began $c a .1980$ in order to study vascular plants in the southern Mexican state of Guerrero. As a result, 53 taxonomic treatments and 17 floristic studies have been published. The former embraces some works of aquatic or semi-aquatic plants, e.g. DiegoPérez (1997), Domínguez and Fonseca (2001), and Bonilla-Barbosa (2001), besides nine issues specifically on pteridophytes, including a check list containing 29 families, 87 genera and 375 species found in Guerrero (Lorea-Hernández and Velázquez, 1998). Mickel and Smith (2004) published the epic work The Pteridophytes of Mexico, but, surprisingly, despite these previous studies, the Isoëtaceae had not been reported in this state. During field work in the coastal plain area, the Isoëtaceae has finally been discovered.

\section{Methods}

The specimens E. Velázquez, 1884 and 2952 were collected in the state of Guerrero, $16 \mathrm{~km}$ east of Acapulco, near San
Marcos, on the road to Monte Alto, $c a .50 \mathrm{~m}$ above sea level, at $16^{\circ} 43^{\prime} 30^{\prime \prime}$ North latitude and $99^{\circ} 27^{\prime} 41^{\prime \prime}$ 'West longitude. It is an open woodland area, with a grassy meadow seasonally flooded. The surrounding vegetation is a tropical deciduous forest with Acacia cochliacantha, A. farnesiana, Byrsonima crassifolia, Coccoloba barbadensis, Curatella americana, Erythroxylum mexicanum, and Trichilia hirta, in the open area, currently a water pond, there are different species of aquatic or semi-aquatic plants of Cyperaceae (Fimbristylis spadicea, F. littoralis, Lipocarpha micrantha), and Alismataceae (Equinodorus andrieuxii, Sagittaria guayanensis) growing together with Isoëtes.

All dry specimens of Isoëtes at ENCB and MEXU herbaria were reviewed. An isotype of Isoëtes pallida (Kral 25320), which had not been previously reported, was unexpectedly found at ENCB. Its megaspores and microspores were reviewed and photographed, along with those of $I$. montezumae A.A.Eaton from McVaugh 17600 (MEXU), in order to compare them with those of the reference plants and to confirm the taxonomic determination, since both species, among Mexican material, are very similar.

The megaspores and microspores of plants collected in Guerrero were photographed with a scanning electronic microscope model JEOL, JSM-5310LV. The spore size of 20 megaspores and 20 microspores was determined under a light microscope, fitted with an ocular micrometer. The spore and sporangial wall ornamentation, as well as its color, and velum were determined in the same manner. The average size of 15 sporangia was determined with micrometer.

The specimens collected in this research will be deposited in ENCB, FCME, and MEXU Herbaria.

\section{Results}

The collected plants were determined to be Isoëtes pallida Hickey. This species has corm globose, two or threelobed; roots dichotomous. Leaves $20-45$, to $30 \mathrm{~cm}$ long, 4.5-8.0 $\mathrm{mm}$ wide at the base, $0.5-1.5 \mathrm{~mm}$ wide at mid-length, stiffly erect; alae $30-80 \mathrm{~mm}$ long, $1-1.5 \mathrm{~mm}$ wide at the sporangium, chartaceous and nearly transparent, each apex attenuate; subula trigonal, stramineous to bright green, the apex attenuate; peripheral fibrous bundles distinct; stomata present; scale leaves present, phyllopodia absent. Sporangia 3.6-4.0 mm long, 2.5-4.0 mm wide, ovate, tan, unspotted, basal. Vela absent. Ligules not seen. Labia 0.9-1.5 mm high, 1.0-1.2 $\mathrm{mm}$ wide, depressed-ovate to widely depressed-ovate, submembranaceous, tan, erose-entire to mucronate, the mucro to $0.45 \mathrm{~mm}$ long. Megaspores 390-460 $\mu \mathrm{m}$ $(\overline{\mathrm{x}}=426)$ diam., white, pustulate, with 70 or more pustules on the distal surface, these subacute, and evenly distributed, and equally well developed on all surfaces, rarely anastomosing; equatorial and proximal ridges distinct, triangular in cross-section, the equatorial ridge rarely scalloped; microspores not seen (Hickey, 1988). 
The short description of the same taxon from Mickel and Smith (2004) is slightly different in the following characters: velum covering less than $25 \%$ of each sporangium, the megaspores 400-475 $\mu \mathrm{m}$ average diameter, and the microspores 25-35 $\mu \mathrm{m}$ long, with echinate surface ornamentation.

The specimens from Guerrero agree with both previous descriptions, except that the sporangial walls of the former are spotted (Figure 1A), the slightly higher average size of megaspores, (Figure 1B, C), and the slightly wider average size of microspores (Figure 1D), but the most noteworthy difference is the twice average size of sporangia (Table 1).

\section{Discussion}

The discovery of Isoëtes pallida constitutes the first report for the state of Guerrero and the third for Mexico. This species had previously been reported for Campeche and Oaxaca (Mickel and Smith, 2004).
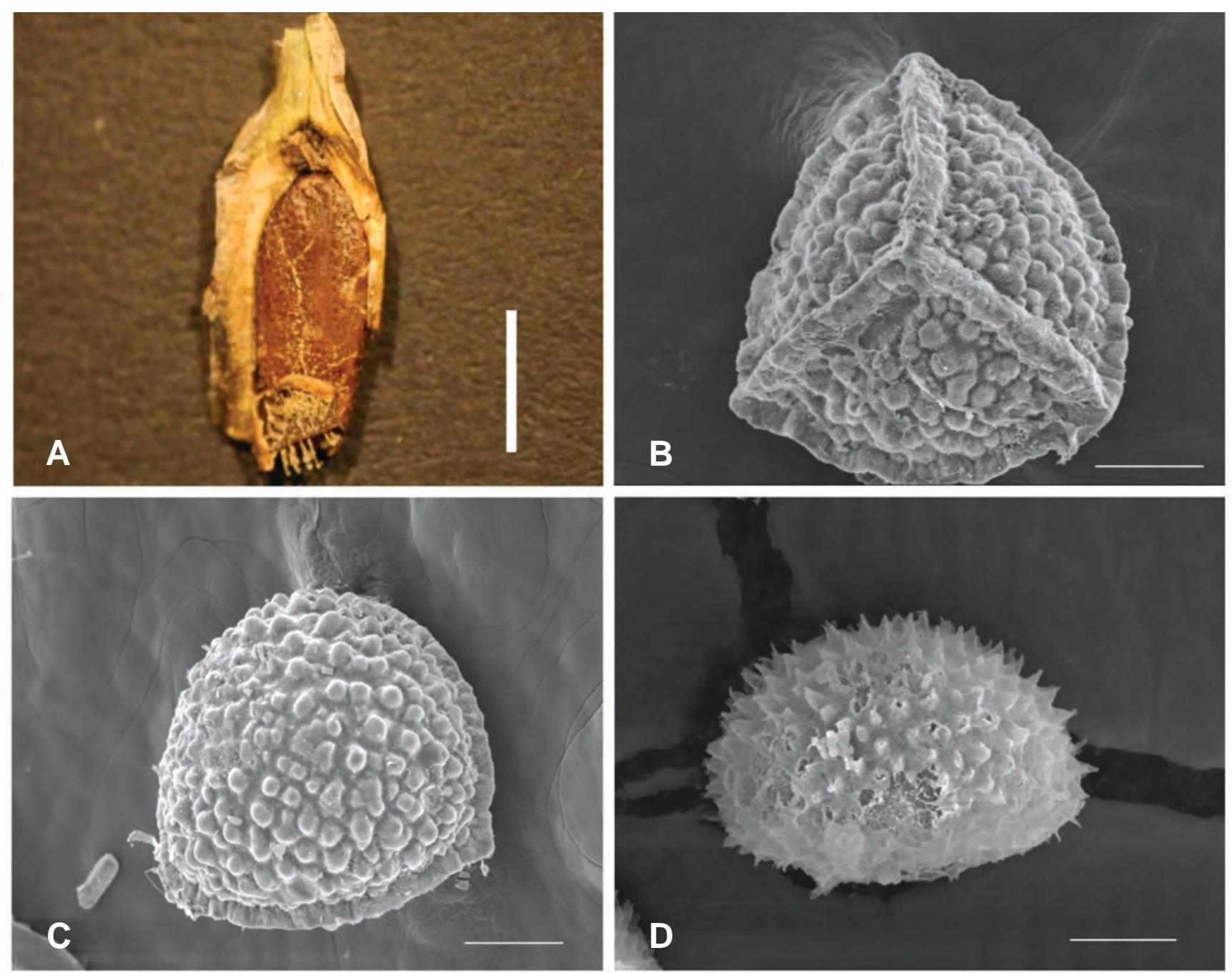

Figure 1. Isoëtes pallida. A. Microsporangium showing sporangial wall with dark brown spots; B. Megaspore, proximal polar view; C. Megaspore, distal polar view; D. Microspore, distal polar view. Bar scale in A = $2.13 \mathrm{~mm}, \mathrm{~B}-\mathrm{C}=100 \mu \mathrm{m}, \mathrm{D}=10 \mu \mathrm{m}$. 


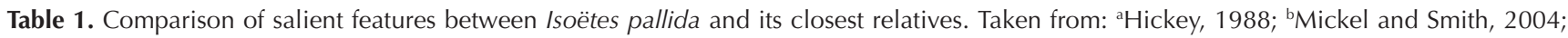

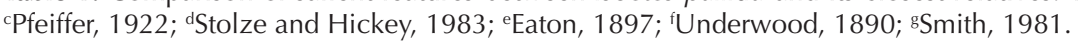

\begin{tabular}{|c|c|c|c|c|c|c|c|c|}
\hline \multirow{2}{*}{$\begin{array}{l}\text { Taxa } \\
\text { (references) }\end{array}$} & \multicolumn{2}{|l|}{ Megaspores } & \multicolumn{2}{|c|}{ Microspores } & \multicolumn{2}{|l|}{ Sporangia } & \multirow[t]{2}{*}{ Velum } & \multirow{2}{*}{$\begin{array}{l}\text { Mid-length } \\
\text { transection } \\
\text { of leaves }\end{array}$} \\
\hline & $\begin{array}{l}\text { Distal surface } \\
\text { ornamentation }\end{array}$ & $\begin{array}{l}\text { Diameter } \\
(\mu \mathrm{m})\end{array}$ & $\begin{array}{l}\text { Surface } \\
\text { ornamentation }\end{array}$ & $\begin{array}{l}\text { Long } \\
(\mu \mathrm{m})\end{array}$ & Wall & $\begin{array}{l}\text { Long } \\
(\mathrm{mm})\end{array}$ & & \\
\hline I. pallida $a^{\mathrm{a}, \mathrm{b}}$ & $\begin{array}{l}\text { pustulate. } 70 \text { or } \\
\text { more subacute } \\
\text { pustules, evenly } \\
\text { distributed. }\end{array}$ & $\begin{array}{l}390-460 \\
\bar{x}=426\end{array}$ & echinate & $\begin{array}{l}25-35 \\
\bar{x}=?\end{array}$ & $\begin{array}{l}\text { tan? clear? } \\
\text { unspotted }\end{array}$ & $3.6-4.0$ & $\begin{array}{l}\text { absent or } \\
\text { covering } \\
\text { less that } 25 \% \\
\text { of each } \\
\text { sporangium }\end{array}$ & triangular \\
\hline $\begin{array}{l}\text { I. pallida } \\
\text { (Specimens } \\
\text { from Guerrero) }\end{array}$ & $\begin{array}{l}\text { pustulate. } 70 \text { or } \\
\text { more subacute } \\
\text { pustules, evenly } \\
\text { distributed. }\end{array}$ & $\begin{array}{l}404-484 \\
\bar{x}=440\end{array}$ & echinate & $\begin{array}{l}18-37 \\
\bar{x}=30\end{array}$ & $\begin{array}{l}\text { tan, } \\
\text { spotted }\end{array}$ & $\begin{array}{l}7.0-11.4 \\
\bar{x}=8.64\end{array}$ & absent & triangular \\
\hline I. cubana ${ }^{\mathrm{c}, \mathrm{d}}$ & $\begin{array}{l}\text { pustulate, } \\
\text { tuberculate. Fewer } \\
\text { than } 40 \text { round and } \\
\text { depressed tubercles } \\
\text { in Cuban material. }\end{array}$ & $\begin{array}{l}290-400 \\
\bar{x}=351\end{array}$ & tuberculate & $\begin{array}{l}26-30 \\
\bar{x}=29\end{array}$ & $\begin{array}{l}\text { tan, } \\
\text { unspotted }\end{array}$ & $4-7$ & very narrow & triangular \\
\hline I. montezumae ${ }^{\mathrm{b}, \mathrm{d}, \mathrm{e}}$ & $\begin{array}{l}\text { tubercules blunt } \\
\text { or retuse. Smooth } \\
\text { or obscurely to } \\
\text { boldy tuberculate- } \\
\text { verrucate. }\end{array}$ & $\begin{array}{l}350-660 \\
\bar{x}=510\end{array}$ & $\begin{array}{l}\text { echinate- } \\
\text { tuberculate }\end{array}$ & $\begin{array}{l}35-48 \\
\bar{x}=39\end{array}$ & $\begin{array}{l}\text { brownish } \\
\text { spotted, lightly } \\
\text { spotted to } \\
\text { unspotted }\end{array}$ & $3-5$ & $\begin{array}{l}\text { very narrow } \\
\text { to absent }\end{array}$ & triangular \\
\hline I. pringleib ${ }^{\mathrm{b}, \mathrm{fg}}$ & $\begin{array}{l}\text { coarsely and } \\
\text { densely spinulose; } \\
\text { echinate-cristate. }\end{array}$ & $\begin{array}{l}460-650 \\
\bar{x}=?\end{array}$ & smooth & $\begin{array}{l}35-45 \\
\bar{x}=?\end{array}$ & unspotted & $1-12$ & $\begin{array}{l}\text { moderately } \\
\text { narrow }\end{array}$ & half-terete \\
\hline
\end{tabular}

the former has megaspores with an equinate-cristate surface, averaging higher size in diameter, and with leaves half-terete in mid-length transection (Mickel and Smith, 2004).

Currently, the spore size and spore wall ornamentation, together with the color and the wall ornamentation of the sporangium, are used to distinguish the different Mexican species of Isoëtes (Mickel and Smith, 2004), but there are several inconsistencies regarding the color and the sporangial wall ornamentation of I. pallida; for example, in the original description, Hickey (1988, p. 35) described the sporangial wall as tan and unspotted, while in the discussion he said it has "unpigmented sporangium...". Later, Hickey (1995, p. 43) described the sporangia of the same species as "marrón, maculado" which means tan and spotted. Taylor and Hickey (2004, p. 354) consider all Mexican species of Isoëtes, except I. montezumae and $I$. howellii, to have a sporangial wall "clear, without brown spots or streaks", which means $I$. pallida has unpigmented and unspotted sporangial wall.

During the review of the isotype specimen at ENCB Herbarium, I observed two sporangia; one of them with a totally unpigmented or clear wall and without spots, but the other one with some little regions of light brown color in its wall, indicating perhaps some degree of maturity. In this sense, I agree with Mickel and Beitel (1988, p. 222), who said about Isoëtes: "Interpretation of the characters is open to much question and few characters can be used with great confidence" and they (op.cit., p. 223) also said with respect the color of megasporangial walls of Isoëtes triangula: "This character, however, may vary with the age of the leaf...". This could be the same situation with the presence or absence of spots on the sporangial wall, because they could reflect the maturing degree of the spores and the sporangial wall indeed. Therefore, it is possible that these two characteristics need to be re-evaluated in order be used confidently to identify, at least, Isoëtes pallida, but this could be apply to all other Mexican species.

Regarding the differences in size of sporangia, megaspores and microspores between the specimens from Guerrero and those of the previous descriptions, these could be considered as intraspecific variation, perhaps for maturing process or for the specific environmental conditions.

The discovery of Isoëtes in the state of Guerrero is significant because it had not been recorded despite many previous efforts, and also because ecologically represents the remains 
of an ancient population, since many species of this genus compete poorly with aquatic angiosperms (Pigg, 1992).

The lack of ecological studies in Mexico in relation with this genus is noteworthy, and had made no attempts in order to evaluate its situation. All Mexican species of Isoëtes are not included in the red list of CITES (2007), neither IUCN (2001), only Isoëtes bolanderi Engelm. is mentioned by SEMARNAT (2002) as a species under protection (Pr), but this taxon is not distributed in Mexico.

The area, in which Isoëtes pallida was collected in Guerrero, is around $100 \mathrm{~m}^{2}$, and aside of a road. There are $a$ priori no more than 100 individuals in this area and with a strong trend to decrease the population size, because the intensive cattle grazing when the water level is reduced. In addition, no other population of this species has been found in the surrounding area, therefore, and according with the criteria of SEMARNAT (2002), this population could be considering as Vulnerable (V) by the moment, but is in need to be evaluated ecologically.

\section{Conclusions}

After many years of search, this study recorded for the first time the monotypic family Isoëtaceae in the state of Guerrero, Mexico; it is represented by Isoëtes pallida, being the third record in the whole country for this species. The literature disagreements in regard to color and ornamentation of the sporangia wall of I. pallida, as well as the possible ontogenetic variation of the color of this structure observed in the isotype, suggest that their taxonomic value needs to be reviewed and re-evaluated, at least in this taxon, but probably in all Mexican species. More studies about Mexican species of Isoëtes are needed, at least in Guerrero, in order to evaluate ecologically this population and to set up strategies for conservation.

\section{Acknowledgements}

Thanks to Raquel Galván, from the ENCB Herbarium of Instituto Politécnico Nacional, who allowed me to review spores of the isotype of Isoëtes pallida. Silvia Espinosa Matías photographed the spores in the scanning electronic microscope. Eduardo Domínguez Licona, Rosa María Fonseca, and the students of the course of Plant Taxonomy, who assisted me during field work. Curators of MEXU, ENCB and IEB Herbaria let me reviewed their collections. Ana Isabel Bieler Antolín and José Antonio Hernández Gómez photographed and edited the sporangium. Comments of three anonymous reviewers allowed improving the manuscript.

\section{Literature cited}

Amstutz E. 1957. Stylites, a new genus of Isoëtaceae. Annals of the Missouri Botanical Garden 44:121-123.
Bonilla-Barbosa J.R. 2001. Nymphaceae. In: Diego-Pérez N. y Fonseca R.M. Eds. Flora de Guerrero. No. 13, Prensas de Ciencias, Universidad Nacional Autónoma de México, México, D.F.

CITES. Convention on International Trade in Endangered Species of Wild Fauna and Flora. 2007. Apéndices I, II y III. <http:// www.cites.org/eng/app./e-appendices.pdf> (consultado 18 de junio de 2013)

Diego-Pérez N. 1997. Cyperaceae. In: Diego-Pérez N. y Fonseca R.M. Eds. Flora de Guerrero. No. 5, Prensas de Ciencias, Universidad Nacional Autónoma de México, México, D.F.

Domínguez E. and Fonseca R.M. 2001. Alismataceae. In: DiegoPérez N. y Fonseca R.M. Eds. Flora de Guerrero. No. 14. Prensas de Ciencias, Universidad Nacional Autónoma de México, México, D.F.

Eaton A.A. 1897. A new quillwort from Mexico. Fern Bulletin 5:25.

Christenhusz M.J.M., Zhang X. and Schneider H. 2011. A linear sequence of extant families and genera of lycophytes and ferns. Phytotaxa 19:7-54.

FNAEC. [Flora of North America Editorial Committee]. 1993. Flora of North America North of Mexico, vol. 2, Pteridophytes and Gymnosperms. Oxford University Press, Oxford.

Hickey R.J. 1988. Isoëtes pallida, a new species from Mexico. American Fern Journal 78:35-36.

Hickey R.J. 1995. Isoëtaceae. En: Moran, R. y Riba R. (Eds. in Pteridophytes). In: Davidse G., Sousa S.M. and Knapp S. Eds. Flora Mesoamericana, vol. 1, Psilotaceae a Salviniaceae, pp. 42-45, Instituto de Biología, Universidad Nacional Autónoma de México, Missouri Botanical Garden, The Natural History Museum (London). México, D.F.

IUCN. International Union for Conservation of Nature. 2001. IUCN Red List Categories and Criteria: Version 3.1. Gland, Switzerland and Cambridge.

Jermy A.C. 1990. Isoetaceae. En: Kramer K.U. and Green P.S.. Ed. The Families and Genera of Vascular Plants. Vol.1. Pteridophytes and Gymnosperms, pp. 26-31, Springer-Verlag, Berlin.

Judd W.S., Campbell C.S., Kellogg E.A., Stevens P.F. and Donoghue M.J. 2008. Plant Systematics. A Phylogenetic Approach. $3^{\text {rd }}$ ed. Sinauer Associates Inc. Sunderland.

León B. 2006. Isoëtaceae endémicas del Perú. Revista Peruana de Biología. 13(2): 905s.

Lorea-Hernández F. and Velázquez E. 1998. Pteridofitas. Lista de los taxa y su distribución geográfica en la entidad. In: DiegoPérez N. y Fonseca R.M. Eds. Estudios Florísticos en Guerrero. No. 9. Prensas de Ciencias, Universidad Nacional Autónoma de México. México, D.F.

Mickel J.T. and Beitel J.M. 1988. Pteridophyte Flora of Oaxaca, Mexico. New York Botanical Garden Press. New York.

Mickel J.T. and Smith A.R. 2004. The pteridophytes of Mexico. New York Botanical Garden Press, New York.

Nelson C., Gamarra R. and Fernández J. 1996. Hondurensis plantarum vascularium catalogus. Pteridophyta. Fontqueria 43.Cyanus. Madrid.

Pfeiffer N.E. 1922. Monograph of the Isoëtaceae. Annals of the Missouri Botanical Garden 9:79-232.

Pigg K.B. 1992. Evolution of Isoetalean Lycopsids. Annals of the Missouri Botanical Garden 79: 589-612.

Rzedowski J. 1991. Diversidad y orígenes de la flora fanerogámica de México. Acta Botanica Mexicana 14:3-21. 
SEMARNAT. Secretaría del Medio Ambiente y Recursos Naturales. 2002. Norma Oficial Mexicana NOM-059-ECOL-2001. Protección ambiental-Especies nativas de México de flora y fauna silvestres-Categorías de riesgo y especificaciones para su inclusión, exclusión o cambio-Lista de especies en riesgo.

Smith A.R. 1981. Pteridophytes. In: Breedlove D.E. Ed. Flora of Chiapas, part 2, pp. 1-370, California Academy of Sciences, San Francisco.

Stolze R. and Hickey R.J. 1983. Isoëtaceae. In: R.G. Stolze Ed. Ferns and fern allies of Guatemala, part III. Marsileaceae, Salviniaceae and the fern allies. Fieldiana, Botany 12, pp. 62-67, Chicago Natural History Museum, Chicago.
Taylor W.C. and Hickey R.J. 1992. Habitat, evolution, and speciation in Isoëtes. Annals of Missouri Botanical Garden 79:613-622.

Taylor W.C. and Hickey R.J. 2004. Isoëtes. In: Mickel J. and Smith A.R. Eds. The Pteridophytes of Mexico, pp. 354-357, New York Botanical Garden Press, New York.

Taylor T.N., Taylor E.L. and Krings M. 2009. Paleobotany. The Biology and Evolution of Fossil Plants. $2^{\text {nd }}$ ed. Academic Press. New York.

Tryon R.M. and Tryon A.F. 1982. Ferns and Allied Plants, with Special Reference to Tropical America. Springer-Verlag. New York.

Underwood L.M. 1890. Notes on the heterosporous fern allies of the pacific coast and Mexico. Zoe 1:97-101

Received: April 11th, 2013

Accepted: July 8th, 2013 